\title{
Legal Protection of the Marine Environment from Oil Refinery Industry Activities in Indonesia (Study on Cilacap and Balikpapan Refinery Industry)
}

\author{
Juajir Sumardi* Marten Napang Mutiah Wenda Juniar \\ Andi Yuzril Muhammad Andriansyah \\ Faculty of Law, Hasanuddin University, Jalan Perintis Kemerdekaan Kampus Unhas Tamalanrea Makassar \\ 90245, Indonesia
}

\begin{abstract}
Legal Protection of the Marine Environment from Oil Refinery Industry Activities in Indonesia aims to analyze the form of integration of environmental law principles in oil refining industry activities in Indonesia, the operationalization of the oil refinery industry which has the potential to cause pollution of the marine environment, as well as forms of countermeasures taken against oil spills into the marine environment. The research location is carried out in the oil refinery industry in Indonesia, especially at the PT. Pertamina (Persero) RU V Balikpapan, and PT. Pertamina (Persero) RU IV Cilacap. The research method used is empirical legal research, with a sociological, conceptual, and statutory approach. Empirical data were obtained through interviews and the distribution of questionnaires to selected respondents, while primary legal materials, secondary legal materials, and tertiary legal materials were obtained through literature study. The empirical data and legal materials obtained were analyzed using content and qualitative analysis.Based on the research conducted, the results were found: (i) the integration of environmental law principles in the oil refining industry activities in Indonesia is carried out through licensing mechanisms in the management, processing, transfer, storage, utilization, disposal and/or landfill waste generated by the production process that takes place in the oil refinery industry; (ii) The operation of the oil refinery industry has the potential to cause pollution of the marine environment because the industrial waste produced is dumped into the sea. In addition, the use of the sea as a means of transportation in loading and unloading activities at the jetty (jetty) and Transfer Ship to Ship (TSS) on the high seas can result in spills of crude oil and fuel oil into the sea which has the potential to cause pollution to the marine environment. Likewise, the potential for leaks from undersea pipes used to transport crude oil from the raw material storage terminal to the processing process also has the potential to cause pollution to the marine environment; (iii) handling of oil spills into the sea from oil industry activities is carried out by implementing a management system for dealing with oil spills to the sea contained in the Standard Procedures made by the Company, the substance of which is to implement the provisions contained in the laws, agreements, and Cooperation, as well as international agreements and standards.
\end{abstract}

Keywords: Legal Protection, Marine Environment, Oil Refinery Industry.

DOI: $10.7176 / \mathrm{JLPG} / 115-09$

Publication date: November $30^{\text {th }} 2021$

\section{Introduction}

Pollution of the marine environment caused by the oil refinery industry occurs from various pollutant sources, which include crude oil transported by tankers to be stored in storage, production processes that produce liquid waste, and waste materials, dangerous toxic, and the distribution process (Helen Wake. 2005).

Efforts to protect the marine environment from the activities of the oil refinery industry can be done in various ways. One of the efforts made is through the establishment and implementation of laws and regulations governing licensing, waste management, handling, and environmental restoration to prevent and reduce the potential for pollution of the marine environment from oil spills from ships and waste materials sourced from oil refineries industry activities. which can lead to environmental pollution.

Based on Government Regulation No. 101 of 2014 concerning Management of Toxic Hazardous Material Waste (THMW), waste from the oil refinery industry is categorized as THMW because its nature and concentration can harm the environment, human health, and other living things. While the characteristics that include LB3 waste are explosive, flammable, reactive, toxic, causing infection, corrosive and carcinogenic, so that proper handling is needed so as not to pollute the environment, including the marine environment in particular.

The business operation process that takes place in the oil refinery industry activities is carried out by the seven oil refineries owned by PT. Pertamina (Persero) starts from the Feed Intake process which includes Jetty Handling, Oil Movement, Piping, and Tank Handling; then proceed with Processing, which includes Production Process, Physical \& Chemical Reaction, and Operation Control; and ends with Product Lifting which includes Blending Management, Oil Movement, and Jetty Handling. In every process of operating the oil refinery 
industry, this has the potential to cause negative impacts on the environment in general, both on the land, sea, and in the air due to the presence of waste in the form of liquid waste, B3 waste, and air emissions (Agung Darmawan. 2021).

\section{Research Questions}

Based on the potential for pollution of the marine environment from the ongoing activities of the oil refinery industry, the legal issue in this study is the maximization of the production process in the oil refinery industry without a consistent legal policy that will cause potential damage to the marine environment. To that end, the problems studied in this study are as follows:

(1) How is the integration of the principles of marine environmental law in the activities of the oil refinery industry in Indonesia?

(2) What is the potential for pollution of the marine environment in the business operations of the oil refinery industry in Indonesia?

(3) What is the form of handling oil spills into the sea from the activities of the oil refinery industry in Indonesia?

\section{Method}

The type of research carried out in empirical legal research using a sociological approach, a statutory approach, and a conceptual approach. This research was conducted at the Oil Refinery Industry owned by PT. Pertamina (Persero) RU IV Cilacap in Central Java Province, and PT. Pertamina (Persero) RU V Balikpapan in East Kalimantan Province.

Samples were taken by random sampling using a simple random method so that the total sample of the study was 50 people as shown in table 1 below:

Tabel 1. Sample of the study.

\begin{tabular}{|c|l|c|}
\hline No. & \multicolumn{1}{|c|}{ Population Types } & Number of Samples \\
\hline 1. & Cilacap Oil Refinery Management & 5 peoples \\
\hline 2. & Balikpapan Oil Refinery Management & 5 peoples \\
\hline 3. & Fishing Society & 40 peoples \\
\hline \multicolumn{2}{|c|}{ Total Number of Samples } & 50 peoples \\
\hline
\end{tabular}

The types of research data in this study are empirical data and legal data (legal materials). For empirical data was collected in the form of structured interviews, questionnaires, and brief observations at industrial locations that took place. The research data in the form of legal materials collected in this study consisted of primary legal materials, secondary legal materials, and tertiary legal materials. The primary legal materials collected are statutory regulations, company regulations, and waste management procedures imposed by oil refinery management. The secondary legal materials collected are legal materials in the form of the results of previous research, manuscripts published in journals, and scientific books related to the title of this research, while tertiary legal materials are legal materials in language dictionaries and legal dictionaries as well as news data published in the media Internet.

For empirical data, the data collection technique was carried out through in-depth interviews and distributing questionnaires, as well as limited observations carried out at industrial waste treatment installations at the Cilacap Oil Refinery and the Balikpapan Oil Refinery. As for the data in the form of primary legal materials obtained by tracing the laws and regulations, and for secondary legal materials and tertiary legal materials obtained by library research techniques and through internet media.

After the empirical data, primary legal materials, secondary legal materials, and tertiary legal materials are collected, then the data is grouped based on the level of validity for further analysis of legal materials using content analysis and qualitative analysis techniques.

\section{Discussion}

\subsection{Integration of Environmental Law Principles in Oil Refinery Industry Activities}

4.1.1 The Principle of Common Responsibility

The implementation of this common responsibility is inspired by the principles and concepts of environmental protection. Legal obligations originating from legal principles are certainly different from legal obligations originating from the rule of law. The referee in the Gentini case (1903) between Italy and Venezuela gave a statement that can be used as a guide in distinguishing principles and rules in international environmental law, "a rule ...is essentially practical and binding. While the principle expresses a general truth, which guides our action, serves as a theoretical basis for the various acts of our life, and the application of which to reality produces a given consequence" (which directs action, as the basic theory of action). The principle contains legal standards that are general Innature and do not regulate specifically, while the rules are the formulation of practical principles (https://hukumlingkungan internasional.blogspot.com/2014/05/prinsip-prinsip-hukumlingkungan.html. Accessed on July 11, 2021). 
The provisions in Article $28 \mathrm{H}$ paragraph (1) of the 1945 Constitution of the Republic of Indonesia have stated that "Everyone has the right to live in physical and spiritual prosperity, to have a place to live, and to have a good and healthy environment and have the right to health services". Based on these arrangements, citizens have the right to enjoy a good and healthy environment, this right is a form of social rights in a fundamental right. The form of embodiment of the right to a good environment is followed up through the enactment of Law No. 32 of 2009 concerning Environmental Protection and Management (hereinafter will be written LEPM).

The principle of common responsibility in national environmental law is integrated into the substance of Article 67 of LEPM which explicitly stipulates that: "Everyone is obliged to maintain the preservation of environmental functions and control pollution and/or environmental damage".

Further implementation of the principle of common responsibility can be found in the substance of Article 68 of LEPM which stipulates that "Everyone who carries out a business and/or activity is obliged to (a) provide information related to environmental protection, and management in a correct, accurate, open, and timely manner; (b) maintain the sustainability of environmental functions; and (c) comply with the provisions on environmental quality standards and/or environmental damage standard criteria".

In oil refinery industry activities, the principle of common responsibility is integrated through regional regulations, both district/city regulations and provincial regulations. Based on the search for primary legal materials, it was found that the enactment of the Cilacap Regency Regional Regulation Number 5 of 2016 concerning Environmental Permits, Environmental Protection, and Management Permits shows the integration of the principle of common responsibility. Likewise, in the Decree of the Governor of East Kalimantan Number 503/4399/LINK/DPMPTSP/VIII/2020 concerning the Permit for Disposal of Wastewater into the Sea to PT. Pertamina (Persero) RU V Balikpapan, shows that the principle of common responsibility in environmental protection and management has also been integrated into the oil refinery industry activities in Balikpapan, East Kalimantan Province.

4.1.2 The Principles of Prevention

The precautionary principle in the 1945 Constitution is integrated into Article $28 \mathrm{H}$ Paragraph (1) and Article 28 I Paragraph (5), while this precautionary principle is also integrated in the TAP MPR RI Number IX/MPR/2001 concerning Agrarian Reform and Resource Management. Nature, in Article 5 asserts as follows: "Maintaining sustainability that can provide optimal benefits, both for current and future generations, while still paying attention to the capacity and support of the environment".

In the activities of the oil refinery industry in Indonesia, this precautionary principle has also been integrated into Article 40 Paragraph (3) of Law Number 22, 2001 concerning Oil and Gas, which affirms the following: "Environmental management as referred to in paragraph (2) in the form of an obligation to prevent and control pollution as well as recover from environmental damage, including post-mining operations obligations".

The principle of prevention in the context of protecting the environment in oil refinery activities based on primary legal material tracing is integrated into regional regulations, both provincial and district/city level regulations. The search for primary legal materials was carried out in Cilacap Regency, the location of the PT. Pertamina (Persero) RU IV Cilacap, it was found that the precautionary principle was implemented in the Cilacap Regency Regional Regulation Number 5 of 2016 concerning Environmental Permits, Environmental Protection, and Management Permits. Article 3 of the Regional Regulation of Cilacap Regency Number 5 of 2016 stipulates as follows:

(1) Every business and/or activity that has an important impact on the environment must have an Environmental Impact Analysis (hereinafter referred to as EIA).

(2) Every business and/or activity that is not included in the mandatory EIA criteria referred to in paragraph (1) must have Environmental Management Efforts and Environmental Monitoring Efforts (hereinafter referred to as EME).

(3) Every business and/or activity that is required to have an EIA or EME must have an environmental permit.

(4) The environmental permit as referred to in paragraph (3) is obtained through stages of activities which include:

a. preparation of EIA and EME;

b. EIAand EME examination; and

c. application and issuance of Environmental Permits.

The provisions contained in Article 3 of the Cilacap Regency Regulation indicate that the principle of prevention in the context of environmental protection and management has been integrated into the regional regulation. The provisions of Article 3 of the Cilacap Regency Regulation apply to the activities of the Oil Refinery Industry owned by PT. Pertamina (Persero) RU IV Cilacap.

4.1.3 Principles of Cooperation

In ELPM Article 70 Paragraph (1), it is stated that "The community has the same and widest possible rights and opportunities to play an active role in environmental protection and management". For this reason, the 
participation of the community to establish cooperation relationships with industrial actors that produce waste that is categorized as THMW has received recognition based on Article 70 Paragraph (3) letter b which affirms as follows: "Community participation is carried out to increase independence, community empowerment, and partnerships".

In the oil refinery industry activities, it turns out that there are two types of activities carried out on the industrial waste produced, namely THMW management activities and disposal activities. THMW management activities are activities that include reduction, storage, collection, transportation, utilization, processing, and/or landfilling. Meanwhile, waste disposal activities are activities of disposing of, placing, and/or importing waste and/or materials in certain quantities, concentrations, times, and locations with certain requirements into certain environmental media.

Based on Article 99 Paragraph (1) and Paragraph (2) of Government Regulation Number 101 of 2014 concerning THMW Management, it is regulated that: "(a) THMW management must be carried out by everyone who generates THMW; (b) if each person as referred to in paragraph (1) is unable to do it himself, the THMW processing shall be submitted to the THMW processor". This provision indicates the possibility of cooperation that is possible in the management of THMW so that the provisions contained in Article 99 Paragraph (1) and Paragraph (2) indicate the integration of the cooperation principle contained in environmental law.

Waste generated by the oil refinery industry is waste that is categorized as Category 1 THMW, and if the waste processing results produce materials that can still be used, then based on Article 54 (1) Government Regulation No. 101 of 2014 regulates it as follows: "The use of THMW as referred to in Article 53 paragraph (1) includes: (a) utilization of THMW as a substitute for raw materials; (b) utilization of hazardous waste as a substitute for energy sources; (c) utilization of THMW as a raw material; and (d) Utilization of THMW under the development of science and technology". In the context of utilizing the processed waste, every activity of utilizing the processed THMW must first obtain a permit from the competent authority, this is explicitly regulated in Article 56 (1) of Government Regulation No. 101 of 2014 which confirms the following: "The use of THMW as referred to in Article 54 is required to have a THMW Management Permit for THMW utilization activities".

If the producer of THMW does not make use of the results of processing THMW, then the producer of the waste may hand over the utilization of the waste to another party. This is under the provisions stipulated in Article 74 as follows:

(1) If everyone who generates THMW, is not able to carry out the utilization of the THMW it produces:

a. utilization of THMW is submitted, or;

b. can export the hazardous waste it produces.

(2) The delivery of the THMW to the THMW Beneficiary as referred to in paragraph (1) letter a is accompanied by evidence of the delivery of the THMW;

(3) A copy of the proof of submission of the THMW as referred to in paragraph (2) shall be submitted to the Minister no later than 7 (seven) days after the submission of the THMW.

Likewise, if the resulting THMW cannot be utilized, the waste producer is obliged to stockpile the resulting THMW as regulated in Article 145 of PP No. 101 of 2014 as follows: "(1) Everyone who generates THMW is obliged to carry out THMW Stockpiling; (2) If each person as referred to in paragraph (1) is unable to carry out the activities on their own, the THMW Landfill is handed over to the THMW Land filler".

By observing the provisions governing the utilization of THMW resulting from processing and landfilling that must be carried out on THMW that cannot be utilized as regulated in Government Regulation No. 101 of 2014, then the provisions governing the utilization and landfilling of THMW provide opportunities for other parties to cooperate in the activities of utilizing and landfilling THMW so that this shows the integration of the cooperation principle in the activities of utilizing and stockpiling industrial waste of oil refinery industry.

In addition to processing, utilizing, and storing THMW, producers are also allowed to dispose of their waste into environmental media with the condition that the dumping activity must first obtain a permit from the Minister of Environment and Forestry. This is as regulated in Article 176 Government Regulation No. 101 of 2014 which affirms the following: "(1) Everyone to be able to dump THMW into environmental media must have a permit from the Minister; (2) Everyone, as referred to in paragraph (1), is the first party to produce THMW; (3) The permit from the Minister as referred to in paragraph (1) is in the form of a hazardous waste dumping permit to environmental media in the form (a) land; and (b) the sea". In this waste disposal activity, the principle of cooperation is also integrated which allows the involvement of third parties in the production of THMW produced by the oil refinery industry to carry out cooperation in transporting waste to be disposed of, both on land and at sea.

4.1.4 Principles of Polluters Pay

The polluter pays principle is a model for allocating and reducing environmental damage and demanding accountability from polluters, whether individuals, companies, or the state, to bear the costs of pollution. The Organization for Economic Cooperation and Development (OECD) establishes this principle as an economic 
principle and as an effective measure in allocating funds for pollution prevention and control measures taken by the state. The application of this principle is the allocation of economic obligations concerning activities that harm the environment, especially in terms of accountability, the use of economic instruments, including competition and subsidies. Disincentives such as penalties and civil liability can also be seen as part of this principle (Alexandre Kiss; Dinah Shelton. 2007).

Concerning the polluter pays principle which is known in national and international environmental law, this principle has also been integrated into Article 198 of Government Regulation No. 101 of 2014 which confirms the following: "Every person who generates THMW, Collector of THMW, Transporter of THMW, Utilizes of THMW, Processor of THMW, and/or Hazardous Waste Collector who conducts Environmental Pollution and/or Environmental Destruction shall implement: (a) Management of Environmental Pollution and/or Environmental Damage; and (b) Restoration of Environmental Functions". Likewise in dumping or waste disposal activities, the polluter pays principle is integrated into Article 199 of Government Regulation No. 101 of 2014 which confirms as follows: "Everyone who dumps THMW who carries out environmental pollution and/or environmental destruction is obliged to carry out: (a) control of pollution and/or environmental damage; and (b) restoration of environmental functions".

The responsibility for dealing with pollution and/or environmental damage, as well as restoring environmental functions has consequences for the existence of financing for these two forms of obligation. Regarding who is obligated to finance the two activities in the event of damage and pollution to the environment, it is emphasized in Article 201 of Government Regulation Number 101 of 2014 which affirms the following:

(1) The minister, governor, or regent/mayor under their authority stipulate a third party to deal with environmental pollution and/or environmental damage at the expense:

(a) Everyone who produces THMW, THMW Collector, THMW Carrier, THMW Utilizer, THMW Processor, and/or Waste Collector THMW as referred to in Article 198; and

(b) Any Person performing THMW Dumping as referred to in Article 199, if the prevention of environmental pollution and/or environmental damage as referred to in Article 200 is not started within a period of no later than 24 (twenty-four) hours since the discovery of environmental pollution and/or environmental damage;

(2) The costs as referred to in paragraph (1) may come from:

(a) funds for the prevention of environmental pollution and/or environmental damage; or

(b) environmental function recovery guarantee fund.

In addition to the responsibility to pay the costs of environmental management and restoration as stated above, if the pollution and/or environmental damage causes harm to the community, in this case, the polluter pays principle is integrated into the principle of responsibility for the losses suffered by the parties. The third is regulated in LEPM, namely applying the principle of absolute responsibility (strict liability principle).

4.1.5 Principles of Sustainable Development

Concerning the activities of the oil refinery industry in Indonesia, based on the search for primary legal materials, the principle of sustainable development is integrated in Government Regulation Number 101 of 2014 concerning Management of THMW, which expressly stipulates obligations for producers THMW to handle the generated THMW so that the ongoing production process does not damage and/or pollute the environment which may hinder the ongoing development process.

Due to the delegation of authority of the Minister of Environment and Forestry in granting environmental permits and permits for THMW management to local governments, the search for primary legal materials indicates that the Governor of East Kalimantan issued a decree on granting permits to dispose of wastewater into the sea to oil refinery industry players, namely PT. Pertamina (Persero) RU V Balikpapan, with the issuance of Governor's Decree Number: 503/4399/LINGK/DPMPTSP/VIII/2020 dated August 4, 2020.

\subsection{The Potential of Marine Pollution by Oil Refinery Industry Activities}

4.2.1 Potential for Marine Pollution due to Liquid Waste

The oil refinery industry based on Law Number 22 of 2001 concerning Oil and Natural Gas is classified as a Downstream Business Activity that carries out processing of raw materials in the form of crude oil to become finished products according to the choice of products of each oil refinery industry.

Based on the researcher's interview with Mr. Joko Pranoto, General Manager at PT. Pertamina (Persero) RU IV Cilacap (2021), there are 3 types of waste generated, namely:

(1) Liquid Waste;

(2) Hazardous Toxic Waste; and

(3) Waste in the form of Air Emissions.

The business process that takes place in the oil refinery industry based on the researcher's interview with $\mathrm{Mr}$. Hatim Ilwan (2021), Unit Manager of Communication Relations \& CSR Refinery Unit IV Cilacap, "the ongoing business process starts from the Feed Intake process which includes Jetty Handling, Oil Movement, and Piping 
\& Tank Handling. This process is the receipt of crude oil for further storage in the Feed Tank to accommodate the Crude Oil to be processed, where all of the Domestic Crude Oil is processed at the oil refinery owned by PT. Pertamina (Persero) RU IV Cilacap, and the shortage of raw material supply for crude oil is met directly through imports of crude oil". From the production process that takes place at the RU IV Cilacap Oil Refinery, there are 3 types of products, namely: (1) Fuel; (2) Lube Base; and (3) Petro Chemicals.

Based on the results of the researcher's interview with Ms. Fany A.R, from the PSM Reg Analyst Section at the RU IV Cilacap Oil Refinery, she said that for liquid waste at the Cilacap Oil Refinery location, there are 4 types of liquid waste, namely:

(1) Wastewater resulting from ongoing processes;

(2) Wastewater drainage;

(3) Cooler wastewater (cooler water); and

(4) Domestic wastewater.

For the four types of liquid waste, after the researchers conducted a direct survey in the field, it turned out that all of them were channeled to the Donan River Estuary, which in the end went directly to the sea. However, before discharge or disposal to Donan River Estuary, the 4 types of liquid waste are treated or handled first to reduce the quality standard of the liquid waste so that it can be released or disposed of.

Before the liquid waste is released and discharged into the Donan River Estuary, monitoring of the liquid waste management process is carried out, in particular, monitoring the quality of waste carried out by an accredited laboratory, and carried out continuously, including monitoring the PH of liquid waste and discharge daily. According to Article 1 point 3 of the Minister of Environment and Forestry Number P.68/Menlhk/Setjen/Kum.I/8/2016 concerning Domestic Wastewater Quality Standards, the meaning is given as follows: "Wastewater quality standards are limits or levels of elements pollutant and/or the number of pollutant elements whose presence is tolerable in wastewater to be disposed of or released into water sources from a business and or activity".

At the Cilacap Unit Refinery IV Oil Refinery owned by PT. Pertamina (Persero), based on the results of the researcher's interview with Mr. Hatim Ilwan, the process of managing liquid waste for domestic wastewater is carried out based on applicable laws and regulations, in this case, is for the processing through Domestic Wastewater Management Installation (WMI), the process that takes place is based on the provisions contained in the Regulation of the Minister of Environment and Forestry Number: P.68/Menlhk/Setjen/Kum.I/8/2016 concerning Domestic Wastewater Quality Standards.

Domestic wastewater treatment is carried out so that the wastewater to be disposed of and/or released into the environmental media must first meet the requirements of the wastewater quality standard stipulated in the Minister of Environment and Forestry P.68/Menlhk/Setjen/Kum.I/8 /2016 concerning Domestic Wastewater Quality Standards. Based on Article 3 of the Minister of Environment and Forestry P.68/Menlhk/Setjen/ Kum.I/8/2016 concerning Domestic Wastewater Quality Standards, it is regulated that business actors should manage domestic wastewater, as follows:

(1) Every business and/or activity that produces domestic wastewater is obligated to treat the domestic wastewater it produces.

(2) Domestic wastewater treatment as referred to in paragraph (1) is carried out by:

a. separately, without combining it with wastewater treatment from other activities; or

b. integrated, through the incorporation of wastewater from other activities into a single wastewater treatment system.

(3) Separate wastewater treatment as referred to in paragraph (2) letter a must meet the wastewater quality standards as contained in Attachment I which is an integral part of this Ministerial Regulation.

Based on Article 8 Paragraph (3) of the Minister of Environment and Forestry P.68/Menlhk/Setjen/Kum.I/ 8/2016 concerning Domestic Wastewater Quality Standards, it is emphasized that the person in charge of domestic wastewater treatment facilities and infrastructure must meet the following provisions: (a) have an environmental permit; (b) have a wastewater disposal permit, and; (c) under the domestic wastewater quality standard as stated in the Attachment of the Ministerial Regulation.

With the requirements regarding the quality standards of domestic wastewater as regulated in the Regulation of the Minister of Environment and Forestry as stated above, if the domestic wastewater is discharged or released into the marine environment media, and the domestic wastewater does not meet the requirements wastewater quality standards that can be disposed of, then in this condition the potential for pollution of the marine environment.

For liquid waste resulting from the ongoing refining process, the wastewater management process is carried out based on the Regulation of the Minister of the Environment Number 19 of 2010 concerning Wastewater Quality Standards for Oil and Gas and Geothermal Business and/or Activities. Based on Article 10 of the Regulation of the Minister of the Environment Number 19 of 2010 concerning Wastewater Quality Standards for Oil and Gas and Geothermal Business and/or Activities, it is regulated the obligations and procedures for 
processing wastewater as follows:

The person in charge of the oil and gas and geothermal business and/or activity must:

a. carried out wastewater management so that the quality of wastewater discharged into the environment does not exceed the established wastewater quality standards;

b. periodically checking the level of the wastewater quality standard parameters as contained in the Attachment to this Ministerial Regulation at least 1 (one) time a month in an accredited laboratory;

c. formulation procedures for handling abnormal and/or emergency conditions; and specifically for oil and gas processing activities:

1) install a measuring instrument for the discharge or rate of wastewater and record the daily discharge of the wastewater;

2) submit a report on the recording of daily discharge and levels of parameters of the quality standard of wastewater as referred to in letters $b$ and $c$ at least once every 3 (three) months to the Regent/Mayor, Governor, Minister, and technical agencies.

d. reported the occurrence of abnormal conditions within 2 × 24 hours, and emergency conditions within $1 \times 24$ hours to the Regent/Mayor, Governor, Minister, and technical agencies;

e. handling abnormal or emergency conditions by carrying out the handling procedures that have been determined, so as not to endanger human safety, and health, and not cause pollution and/or environmental damage.

Regarding the quality standard parameters of liquid waste that can be disposed of and/or channeled into marine environmental containers, the table below can be stated:

Table 2. Wastewater Quality Standards from Oil and Gas Exploration and Production Facilities in Off-Shore (Off-Shore)

\begin{tabular}{|l|l|l|c|l|}
\hline No. & \multicolumn{1}{|c|}{ Wastewater Type } & \multicolumn{1}{|c|}{ Parameter } & Rate & \multicolumn{1}{c|}{ Measurement Method } \\
\hline 1 & Produced Water & Oil and fat & $50 \mathrm{mg} / \mathrm{L}$ & SNI 06-6989.10-2004 \\
\hline 2 & Drainage Wastewater & Oil-Free & Nihil & Visual \\
\hline 3 & Domestic Wastewater & Floating objects and foam & Nihil & Visual \\
\hline 4 & Sanitary Wastewater & Chlorine Residue & $2 \mathrm{mg} / \mathrm{L}$ & Standard Method $4500-\mathrm{Cl}$ \\
\hline
\end{tabular}

Source: Attachment to Regulation of the Minister of Environment Number 19 of 2010 concerning Wastewater Quality Standards for Oil and Gas and Geothermal Business and/or Activities.

Based on Table 2 above, the management of liquid waste in the oil refinery industry in Indonesia must pay attention to the following: (1) offshore oil and gas exploration and production facilities are facilities used for exploration, drilling, production wells, injection wells, well treatment, and oil and gas processing facilities of the oil and gas industry located at sea; (2) does not contain free oil, in the sense of causing an oil film or discoloration on the surface of the receiving water body; (3) there are no floating objects and foam; (4) The results of internal observations are included in the daily logbook.

As regulated in Government Regulation Number 101 of 2014 concerning Management of Toxic Hazardous Waste, which is further followed up by the Regulation of the Minister of Environment and Forestry, namely the Regulation of the Minister of the Environment Number 19 of 2010 concerning Wastewater Quality Standards for Oil and Gas and Heat Businesses and/or Activities Earth, and Regulation of the Minister of Environment and Forestry P.68/Menlhk/Setjen/Kum.I/8/2016 concerning Domestic Wastewater Quality Standards, all of which require a wastewater disposal permit. In this regard, based on the field data obtained, the RU IV Cilacap Oil Refinery Industry has obtained a wastewater disposal permit with Permit Number No. 660.1/271/24.

Based on the results of the researcher's interview with Mrs. Vanny AR, staff of the PSM Analyst at the RU IV Cilacap Oil Refinery Industry, it was explained that to minimize the potential for pollution to the marine environment caused by discharged liquid waste, environmental monitoring was carried out regularly, namely monthly, monthly monitoring quarterly, per semester and annual reporting provided to the relevant agencies

Regarding the liquid waste that is released and disposed of at the Donan River Estuary, and to find out the extent of the impact on the marine environment around the Donan River estuary, the researchers then distributed questionnaires to 20 coastal fishermen to find out their views, opinions, and its influence on income in traditional fishing activities carried out. The responses of fishing communities to the existing conditions of the marine environment around the Donan River Estuary can be stated in the table below. 
Table 3. Fisherman community responses to marine environmental conditions around the Estuary of the Donan River Cilacap.

\begin{tabular}{|c|c|c|c|c|c|}
\hline \multirow[b]{2}{*}{ No. } & \multirow[b]{2}{*}{ Questions Asked } & \multicolumn{3}{|c|}{$\begin{array}{l}\text { Fisherman Community } \\
\text { Response }\end{array}$} & \multirow{2}{*}{$\underset{t}{\text { Amoun }}$} \\
\hline & & Yes & No & Do not know & \\
\hline (a) & (b) & (c) & (d) & $(\mathrm{e})$ & $(f)$ \\
\hline 1 & $\begin{array}{l}\text { Knowing Oil Refinery Liquid Waste } \\
\text { thrown into the mouth of the Donan River }\end{array}$ & 18 & 0 & 2 & 20 \\
\hline 2 & $\begin{array}{l}\text { Doing fishing in the sea around the mouth of the Donan } \\
\text { River }\end{array}$ & 15 & 5 & 0 & 20 \\
\hline 3 & $\begin{array}{l}\text { Smell a very bad smell sting around the mouth of the river } \\
\text { Donan }\end{array}$ & 15 & 0 & 5 & 20 \\
\hline 4 & $\begin{array}{l}\text { The number of fish caught in the surrounding sea the } \\
\text { mouth of the Donan River is reduced }\end{array}$ & 15 & 0 & 5 & 20 \\
\hline
\end{tabular}

Source: Primary data. June 2021. Processed.

Based on table 3 as stated above, several 20 respondents who were asked to fill out the questionnaire, 90\% knew that the liquid waste generated from the processing was disposed of and released into the mouth of the Donan River Estuary. This shows that the fishing community generally knows that the mouth of the Donan River Estuary is an environmental container for the disposal of liquid waste which eventually flows into the sea which intersects with the river mouth.

Although generally, the fishing community knows that the sea around the Donan estuary has received liquid waste generated by the RU IV Cilacap Oil Refinery, 15 people or $75 \%$ of the 20 respondents continue to fish in the sea around the Donan river estuary, and all respondents those who do fishing in the sea around the mouth of the Donan river smell a strong stench in the sea around the mouth of the Donan river. This was also smelled by the researchers when the researchers inspected the WWTP and the process of disposing of the liquid waste into the mouth of the Donan river.

When the researchers asked 15 respondents who were fishing in the sea around the mouth of the Donan River, it turned out that the 15 respondents all said that the results of their successful catch were very less than if they were fishing in the sea far from the mouth of the Donan River. This phenomenon shows that the existence of the RU IV Cilacap Oil Refinery Industry has affected the fish catches of fishermen around the mouth of the Donan River.

4.2.2 Potential for Marine Pollution due to Hazardous Toxic Material Waste

One of the wastes from the production process that takes place in the oil refinery industry is waste that is categorized as THMW. This type of waste is very dangerous if it is not managed under applicable regulations, especially if this type of waste is discharged into the sea without first being properly treated as required in the applicable laws and regulations. Thus, THMW generated from the production process in the oil refinery industry has the potential to cause pollution to the marine environment. For this reason, the management, utilization, and disposal/hoarding of THMW from the ongoing production process becomes very important to be carried out, monitored, and reported.

Based on the results of field research conducted at the Cilacap Oil Refinery, Central Java and the Balikpapan Oil Refinery, East Kalimantan, in this case at PT. Pertamina (Persero) RU IV Cilacap and at RU V Balikpapan, it was found field data that the THMW processing process in the two oil refinery industries was carried out in the following stages:

a. Identification of THMW;

b. THMW receipts from refinery operations;

c. THME storage in Garbage dump;

d. THMW management by a licensed third party; and

e. Monitoring and reporting.

Based on the results of interviews with researchers with Mr. Hatim Ilwan (Unit Manager of Communications Relations \& CSR at Refinery Unit IV Cilacap), Mrs. Vanny AR (Department of PSM Analysis in the Enviro Department), as well as Mr. Bobby Rama Jaya R (Senior Project Engineer), and Mr. Rudiyanto (Officer I Ind Hygiene), data obtained that the THMW management process is carried out with the stages as stated above, the substance can be stated as follows: (1) for the identification stage, what needs to be done is to record the source, amount and type of THMW; (2) for the stage of receiving THMW from the refinery operation, what needs to be done is the transportation of B3 waste to the B3 waste TPS; and (3) storage of THMW into a Garbage Dump for THMW, in this case for the RU IV Cilacap Oil refinery. Having a Garbage Dump permit number: 660.1/640/24/2018, and having storage facilities under the Amount and Characteristics of the THMW generated, as well as the availability of emergency response equipment at the THMW Garbage Dump. To provide an overview of the things that are the substance of the stages of THMW management in the RU IV 
Cilacap oil refinery industry, the picture below can be presented.

To find out the things involved in the THMW management process, the researchers conducted interviews with Mr. Ir. Hendra is the staff of the Environment Department at PT. Pertamina (Persero) RU V Balikpapan, as well as conducting a direct review of the THMW management facility and witnessing the process of collecting and transporting solid waste classified as THMW carried out by a licensed third party. The results of interviews conducted by researchers can be stated as follows:

(1) THMW management includes identification, reduction, collection, packaging, transportation, storage, labeling, giving symbols, further processing, management reporting, and an emergency response system for THMW;

(2) Identification, reduction, collection in the Work area, packaging, and transportation of THMW are carried out by the relevant Functions/Sections that generate THMW;

(3) Storage, labeling, symbol giving, management reporting, and emergency response systems for THMW are carried out by the Environmental Section; and

(4) Further processing of THMW is carried out by a third party who has a processing permit

THMW management is a very important activity in the oil refinery industry, because if the THMW generated by the ongoing production process is not managed based on good and responsible management principles, then the THMW can cause environmental problems, including causing pollution to the marine environment. For this reason, based on the results of the search for primary legal materials related to THMW management issues in the oil refinery industry in Indonesia, researchers can identify primary legal materials that need to be used as the basis for THMW management as shown in the primary legal source table below.

Table 4. THMW management regulations, guidelines and procedures In the Refinery Unit V Of Oil Refinery Industry Balikpapan

\begin{tabular}{|l|l|}
\hline No. & \multicolumn{1}{|c|}{ Name and Type of Regulation/Guidelines/Procedures for Hazardous Waste Management } \\
\hline 1. & $\begin{array}{l}\text { RU V } 2018 \text { Business Process (Probis) namely Process } 8 \text { Management of HSSE Aspects, No. 8.1.3.8.9 } \\
\text { Regarding Conducting Hazardous Waste Management }\end{array}$ \\
\hline 2. & $\begin{array}{l}\text { Guideline Number A-001/E15100/2017-S9 Rev.0 Regarding the Implementation of Refinary } \\
\text { Operational Excellence Management System }\end{array}$ \\
\hline 3. & Guidelines No. A-001/K-00100/2016 S-9 Rev.1 Regarding Hazardous and Toxic Waste Management \\
\hline 3 & TKI No. C-002/E15510/2015 S-9 Rev.1 Concerning the Management of Used Drum THMW \\
\hline 5. & TKI No. C-003/E15510/2015 S-9 Rev.1 Regarding Hazardous Waste Garbage Dump Management \\
\hline 6. & TKI No. C-006/E15510/2015 S-9 Rev.1 Regarding Carrying Out Oil Cleaning from Trenches \\
\hline 7. & $\begin{array}{l}\text { TKI No. C-011/E15510/2015 S-9 Rev.0 Regarding Emergency Management of Hazardous Waste } \\
\text { Temporary Storage Places }\end{array}$ \\
\hline
\end{tabular}

Source: Search for secondary legal materials, 2021.

With the making of regulations and guidelines that are internal to the company at the Refinery Unit $\mathrm{V}$ Balikpapan as found, the company's management is quite serious in managing THMW generated from the ongoing oil refinery industry process. However, failure to supervise and monitor THMW management activities will put the risk of environmental pollution, including the marine environment.

4.2.3 Potential for Marine Pollution due to Submarine Pipe Leaks

As already stated, in the process of operating the oil refinery business, the sea must be used as a means in the process of receiving raw materials (crude oil) and the distribution process of finished materials as a result of production for marketing. The ongoing acceptance and expenditure process has the potential to cause pollution to the marine environment due to leakage of underwater pipes used for receiving activities from tankers to tanks for storing raw materials, and from holding tanks for oil from refineries to tankers for distribution.

Terminal for Oil and Gas Special Interest Pertamina Refinery Unit V Balikpapan (hereinafter referred to as TUKS MIGAS Pertamina RU V Balikpapan) is one of the Business Units of the Pertamina Refining Directorate whose products are distributed to the eastern part of Indonesia, which is $2 / 3$ of the Republic of Indonesia and some products are distributed to western Indonesia and in export. The products produced include BBM, namely Premium, Kerosene, Solar, Pertadex, and Pertamax, and non-fuel materials. TUKS MIGAS Pertamina RU V Balikpapan has been operating since 1922 and currently supplies up to $26 \%$ of the total fuel demand throughout Indonesia. The TUKS MIGAS Pertamina RU V Balikpapan facility consists of two terminals, namely Lawelawe Terminal and Balikpapan Terminal.

TUKS MIGAS Pertamina RU V Balikpapan has several operational activities, namely loading and unloading of fuel and crude oil, stockpiling (storage), processing of crude oil, and distributing fuel. In a series of activities carried out, some risks may arise from these activities, namely pollution from both land and water sources in the form of oil spills and rupture/leakage of oil distribution pipes under the sea. 
Figure 1. Photo of TUKS MIGAS Pertamina RU V Balikpapan

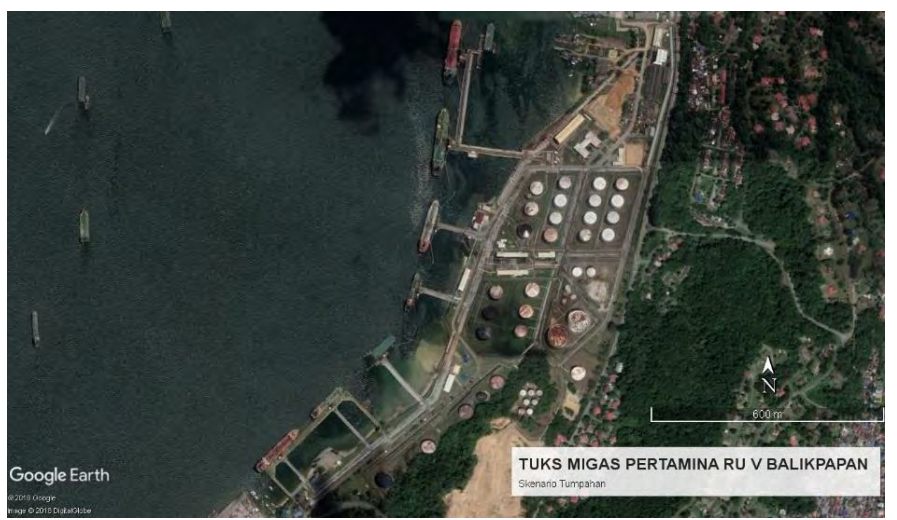

Unloading or receiving of crude oil in the Lawe-lawe Terminal area uses the Single Point Mooring (SPM) mooring facility located in the waters of Tanjung Jumlai, Makassar Strait. Crude oil received from tankers is crude oil originating from abroad. Crude oil that is unloaded from tankers then enters the $17 \mathrm{~km}$ underwater pipeline that goes inland (Jumala Beach) and flows through the inlet pipe on land to the Lawe-lawe Terminal.

Figure 2. Crude Oil Pipeline Unloaded from SPM

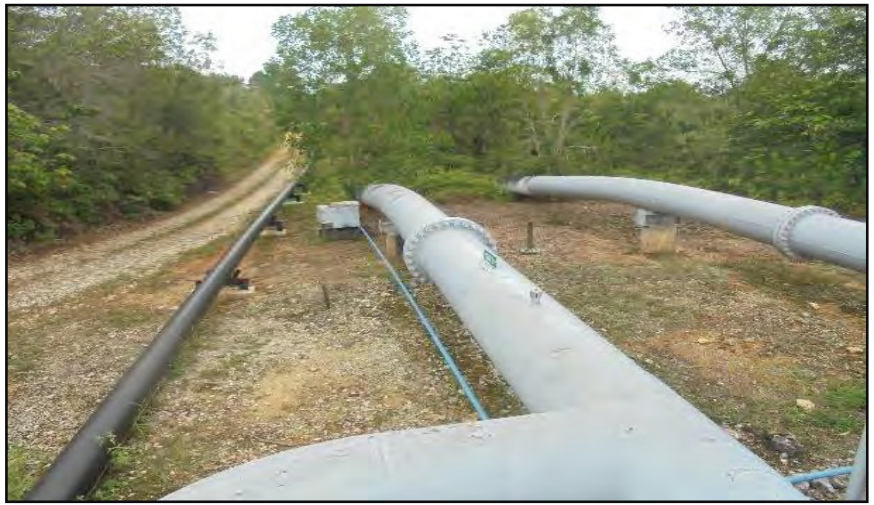

Crude oil received at the Lawe-lawe Terminal will be temporarily stored in a storage tank facility. There are 7 crude oil storage tanks in Lawe-lawe with a total capacity of 5600 MB (@800 MB).

Figure 3. Crude Oil Inlet Pipe from Sharpener

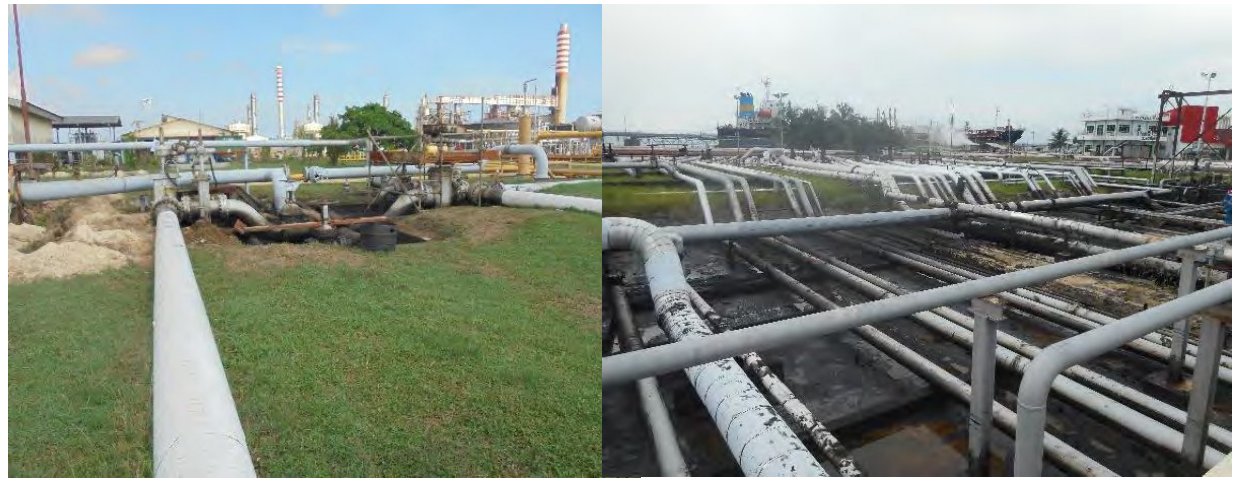

The distribution of SPM Oil to the Lawe-Lawe Terminal can pose a risk of pollution to the marine environment in the event of pipe leaks and pipe ruptures installed under the sea. The rupture of the subsea pipeline from SPM to the storage tank during the shipping process has occurred and has caused pollution to the marine environment around Balikpapan Bay.

4.2.4 Potential Marine Pollution by Oil Spills from Ships

The potential for oil spills into the waters in the working area of TUKS MIGAS Pertamina RU V Balikpapan comes from loading and unloading activities at the jetty, oil distribution, other operational activities, and ship transportation. The potential pollutants include HSD, Premium, Pertamax, Pertamax Turbo, MFO, Kerosene, MDF, and Crude Oil. Unloading or receiving of crude oil in the Lawe-lawe Terminal area uses the Single Point Mooring (SPM) mooring facility located in the waters of Tanjung Jumlai, Makassar Strait. Crude oil received 
from tankers is crude oil originating from abroad.

Crude oil that is unloaded from tankers then enters the $17 \mathrm{~km}$ underwater pipeline that goes inland (Jumala Beach) and flows through the inlet pipe on land to the Lawe-lawe Terminal. In the process of loading and unloading oil from and to tankers, there is the potential for oil spills that can cause pollution to the marine environment.

The loading and unloading activities of crude oil and fuel at RU V Balikpapan use jetty facilities and the Ship to Ship (STS) process. The wharf/jetty is used for loading and unloading domestic crude oil as well as loading and unloading fuel. TUKS MIGAS Pertamina RU V Balikpapan is equipped with 10 docks consisting of 8 jetties (Jetty $1,2,3,4,5,5 \mathrm{~A} / 5 \mathrm{~B} / 5 \mathrm{C}$ ) for loading and unloading activities from and/or to tankers and 2 wharves (Jetty 6 and 7) to dock support vessels and/or charter vessels. In general, loading and unloading activities use the Marine Loading Arm (MLA) and/or flexible hose.

Oil and fuel received from tankers and the Penajam facility will enter the storage tanks through pipelines at the jetty and pipelines in the Balikpapan refinery area. Crude oil will go to processing facilities for further processing and be processed into fuel products such as Premium, Pertamax, Avtur, Kerosene, ADO, IDO/IFO, and MGO. Furthermore, this fuel product will be transferred to tankers or into the Pertamina Balikpapan TBBM. Meanwhile, STS (ship to ship) activities are loading and unloading activities of crude oil and fuel (HSD and MFO) from ship to ship using a hose.

Figure 4. Loading and unloading activities on Ship to Ship

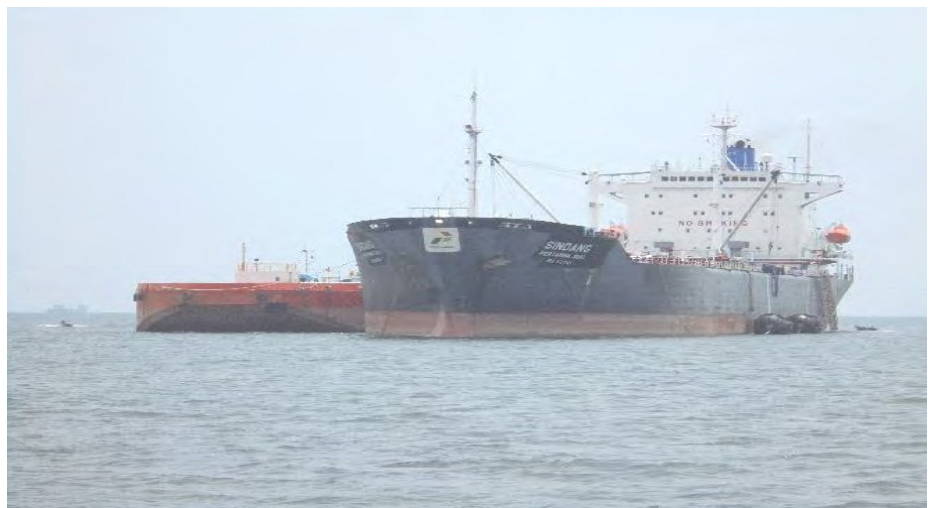

The entire loading and unloading activities of crude oil and fuel (HSD and MFO) from ship to ship as well as loading and unloading are carried out on the 8 jetties owned by PT. Pertamina (Persero) RU V Balikpapan opens up the risk of an oil spill causing pollution to the marine environment. For this reason, protection of the marine environment from oil refinery industry activities is carried out by establishing Standard Procedures for each loading and unloading activity of crude oil and fuel along with countermeasures in the event of an oil spill from ongoing loading and unloading activities.

\section{Handling of Waste and Oil Spills at Sea in the Oil Refinery Industry}

The oil refinery industry is owned by PT. Pertamina (Persero) RU IV Cilacap and RU V Balikpapan have the potential to cause pollution of the marine environment in marine areas around industrial activities. The potential for pollution of the marine environment is caused by sources of pollutants produced by industrial activities, namely the occurrence of dumping of waste into the sea and the occurrence of oil spills into the sea due to loading and unloading activities at the dock and ship to ship transfer activities on the high seas from tankers (TSS).

Disposal of wastewater into the sea can be carried out after obtaining approval from the competent authority in the area where the wastewater disposal activity is carried out. One of the wastewater disposal areas carried out by the RU V Balikpapan Oil Refinery is in North Penajam Paser Regency, which is located at the crude oil storage terminal belonging to the RU V Balikpapan Oil Refinery.

Based on the research conducted, for the disposal of wastewater into the sea carried out at the Crude Oil Storage Terminal in Lawe-Lawe, the local government has issued an approval for the disposal of wastewater to PT. Pertamina (Persero) RU V Balikpapan, namely through the Decree of the Head of the Investment and OneStop Service Office of North Penajam Paser Regency Number: 503/009/DPMPTSP/V/2021 concerning Approval for the Second Extension of the Permit for Disposal of Wastewater to the Receiving Water Agency to PT. Pertamina (Persero) RU V Terminal Lawe-Lawe.

Concerning the approval of the disposal of wastewater into the sea, the disposal of wastewater into the sea can only be carried out if the wastewater to be disposed of meets the requirements of the wastewater quality standards stipulated under the applicable laws and regulations, in this case, the Regional Government is given the authority to determine parameters of wastewater quality standards as regulated in the Regulation of the State 
Minister of the Environment Number: 19 of 2010 concerning Wastewater Quality Standards for Oil and Gas and Geothermal Businesses and/or Activities, which in Article 6 stipulates as follows:

(1) Regional governments may stipulate wastewater quality standards more stringent than the provisions contained in the Attachment to this Ministerial Regulation.

(2) The wastewater quality standard as referred to in paragraph (1) shall be stipulated by provincial regulation.

(3) If the local government does not stipulate a quality standard for wastewater for oil and gas and geothermal business and/or activities, the quality standard for wastewater as contained in the Attachment of this Ministerial Regulation shall apply.

Based on the provisions contained in the Regulation of the State Minister of the Environment Number: 19 of 2010 concerning Wastewater Quality Standards for Oil and Gas and Geothermal Business and/or Activities, the party in charge of oil and gas, and geothermal business and/or activities are obliged to carry out wastewater management so that the quality of wastewater discharged into the environment does not exceed the established wastewater quality standards. In addition, they must check the level of the wastewater quality standard parameters periodically at least 1 (one) time a month in an accredited laboratory, and develop procedures for handling abnormal and/or emergency conditions.

Specifically for oil and gas processing activities, the person in charge of the business should install a measuring instrument for the discharge or rate of wastewater and record the daily discharge of the wastewater to further submit a report on recording daily discharge and levels of parameters of the quality standard of wastewater at least 3 months to the Regent/Mayor, Governor, Minister, and technical agencies. In addition, it is obligatory to report the occurrence of abnormal conditions within $2 \times 24$ hours, and emergency conditions within 1 x 24 hours to the Regent/Mayor, Governor, Minister, and technical agencies, and immediately handle abnormal or emergency conditions by carrying out appropriate handling procedures. has been determined, so that it does not endanger human safety and health, and does not cause pollution and/or environmental damage.

Regarding the conditions that must be met to be able to dispose of waste into the sea, it is specifically regulated in the Regulation of the Minister of Environment and Forestry Number: P.12/MENLHK/SETJEN/KUM.1/4/2018 Concerning Requirements and Procedures for Dumping (Disposal of) Waste into the Sea. Based on this Ministerial Regulation, anyone who produces waste is prohibited from dumping (disposal) waste into the sea without a permit, where waste that can be dumped into the sea includes B3 waste and non-B3 waste.

\section{Conclusion}

Based on the results of research and discussion conducted, it can be concluded as follows:

1. The integration of the environmental law principle in the activities of the oil refining industry is carried out through the establishment of norms in-laws and regulations both a national and regional scale that outlines the principles of shared responsibility, the principle of prevention, the principle of cooperation, the principle of polluter pays, and the principle of sustainable development. The principles of environmental law are implemented in the activities of the oil refinery industry as outlined in the Operating Procedure System (OPS) and Fixed Procedures (FP) in the management of liquid waste, industrial waste which is categorized as THMW, and non-THMW. The management, processing, transfer, storage, utilization, and disposal/hoarding of waste produced by the oil refinery industry can only be carried out after a permit has been issued from the competent authority.

2. The operation of the oil refinery industry has the potential to cause environmental pollution in general, and the marine environment in particular. This is because the industrial waste produced can be dumped into the sea by first obtaining permission from the authorized government agency. In addition, the use of the sea as a means of transportation in the procurement of raw materials in the form of crude oil whose loading and unloading is carried out at the jetty and the Transfer Ship to Ship (TSS) on the high seas, this can result in crude oil spills. as well as fuel oil (BBM) produced to the sea which has the potential to cause pollution to the marine environment. Likewise, the potential for leaks from undersea pipelines used to transport crude oil from the raw material storage terminal to the processing process also has the potential to cause pollution to the marine environment.

3. Handling of oil spills into the sea from oil industry activities is carried out by implementing a management system for handling oil spills into the sea contained in the Standard Procedures (Protap) made by the Company, the substance of which is to implement the provisions contained in national laws and regulations, regional agreements and cooperation, as well as international agreements and standards in the prevention of marine pollution by oil. At PT. Pertamina (Persero) RU V Balikpapan, related to the anticipation of overcoming marine pollution by oil spilled into the sea, the management formed 5 (five) Divisions which were given the responsibility to handle the problem of oil spills into the sea by dividing the operating area of each division. 


\section{Recommendations}

1. For the principles of national and international environmental law to be implemented in the activities of the oil refinery industry in Indonesia, it is necessary to provide a balanced opportunity for the public to take part in industrial waste management activities and the prevention of oil spills into the sea. It is recommended that the government and business entities facilitate the establishment of an integrated partnership pattern between local governments, companies, and communities around the industry through the establishment of Environmental Care Community Groups.

2. In connection with the potential for marine pollution caused by oil refinery industrial activities, it is recommended that oil refinery company budget for the Environmental Fund (EF) as part of the reserve fund to deal with the pollution that arises, so that when an incident occurs, pollution caused by industrial waste or oil spills, the company has a budget that has been reserved.

3. Oil refinery industry companies need to provide adequate equipment for the prevention of marine pollution by oil originating from undersea pipeline leaks and oil spills from ships in the loading and unloading activities of crude oil (crude oil) and fuel oil (BBM). For this reason, the Regional Environment Agency must be consistent in monitoring the company's readiness to prevent and control marine pollution by oil.

\section{References}

Abdulkadir Muhammad, (2010), Hukum Perusahaan Indonesia. Bandung: Citra Aditya Bakti.

Adebayo Oluwaseyi Olayiwola, (2012), Legal Protection of the Marine Environment and Sustainable Development in Nigeria. Submitted to the Faculty of Law in Partial Fulfillment of the Requirements for the Award of Bachelor of Laws (LL., B) Degree.

Agung Darmawan, (2020), Pengolahan Limbah Industri pada PT. Pertamina (Persero) RU IV Cilacap. Power Poin Bahan Presentasi.

Alexandre Kiss \& Dinah Shelton. (2007). International Environmental Law. Leiden: Martinus Nijhoff Publishers. Alexandre Kiss \& Dinah Shelton. (2007). Guide to International Environmental Law, Leiden: Martinus Nijhoff Publishers.

A. Sony Keraf, (2002), Etika Lingkungan. Jakarta: Penerbit Kompas.

Desni Bram, (2013), Politik Hukum Pengelolaan Lingkungan Hidup. Malang: Setara Press.

Celina Tri Siwi Kristiyanti, (2008), Hukum Perlindungan konsumen. Jakarta: PT. Sinar Grafika.

Dinas Lingkungan Hidup Kabupaten Sleman. Teori-teori Lingkungan Hidup. https://dinlh.slemankab.go.id/teori-teori-lingkungan-hidp/, diakses pada tanggal 3 Juni 2021.

Emil Salim, (1982), Lingkungan Hidup dan Pembangunan. Jakarta: Mutiara.

E Suherman, (2000), Aneka Masalah Hukum Kedirgantaraan (Himpunan Makalah 1961-1995). Bandung: Mandar Maju.

Evi Purnamawati, (2018), Perlindungan dan Pengelolaan Lingkungan Hidup dalam Pembangunan yang Berkelanjutan. Jurnal Bina Hukum Lingkungan Volume 3, Nomor 1, Oktober 2018.

Fakhruddin, (2004), Dampak Tumpahan Minyak Pada Biota Laut. Jakarta: Kompas.

Ginting, Pedana, (2007), Sistem Pengelolaan Lingkungan dan Limbah Industri. Jakarta: Kompas.

Helen Wake, (2005), Oil refineries: a review of their ecological impacts on the aquatic environment. Estuarine, Coastal and Shelf Science Volume 62, Issues 1-2, January 2005.

Koesnadi Hardjasoemantri, (1999), Hukum Tata Lingkungan, Cetakan ke-14, Yogyakarta: Gadjah Mada University Press.

Malcolm N. Shaw, (2004), International Law, Edisi Kelima, Cambridge University Press, Cambridge.

Mochtasor, (2007), Pencemaran Pesisir dan Laut. Jakarta: Pradnya Paramita.

Munadjat Danusaputro, (1980), Hukum Lingkungan Buku I: Umum. Bandung: Binacipta.

Popoola, Ademola O, (1997), International Law and the Protection of the Marine Environment: Problems and Challenges for Africa in the $21^{\text {st }}$ century. Paper presented at the International Conference on Environmental Strategy in the $21^{\text {st }}$ century, Lagos State University, 19 ${ }^{\text {th }}-21^{\text {st }}$ March 1997 . Published in 1998 by LAW CENTRE, FACULTY OF LAW, LAGOS STATE UNIVERSITY.

Risdianta. Tth. Mengenal Kilang Pengolahan Minyak Bumi (Refinary) di Indonesia.https://www. bing.com/search?q=Mengenal+Kilang+Pengolahan+Minyak+Bumi+di+Indonesia\&cvid=3146a2cb4e374b0 1bd2a2fb 8eebc85d6\&aqs=edge..69i57.27561j0j4\&FORM=ANAB01\&PC=LCTS.

Satjipto Rahardjo, (1993), Penyelenggaraan Keadilan Dalam Masyarakat Yang Sedang Berubah, Jurnal Masalah Hukum.

Sengupta A. Treatment of Effluents of Petroleum Refining Industry Environmental Engineering. https://www.engineeringennotes.com/environemental-engineering/ Treatment-of-Effluents/treatment-ofPetroleum-Refining-Industry-environmental-engineering/16879.

Titik Triwulan dan Shinta Febrian. 2010. Perlindungan Hukum bagi Pasien. Jakarata: Prestasi Pustaka.

Yu, Zhihao, (2005), Environmental Protection: A Theory of Direct and Indirect Competition for Political Influence. The 
Review of Economic Studies, vol. 72, no. 1, 2005, pp. 269-286. JSTOR, www.jstor.org/ stable/3700692.

\section{Internet:}

http://www.Imfeui.com/data/analisis/industri minyak. Diakses pada 30 Juni 2021.

https://indonesia.go.id/narasi/indonesia-dalam-angka/ekonomi/Kemandirian Energi di Depan Mata. Diakses pada 30 Juni 2021.

https://www.portonews.com/2017/oil-and-chemical-spill/tumpahan-minyak-dampak-dan-upayapenanggulangannya/diakses pada 12 Januari 2020.

https://id.wikipedia.org/wiki/Limbah_minyak\#Pengeboran_di_laut. Diakses 19 Januari 2021.

http://members.tripod.com/sd_east_timor/PROC\%20Papers/Institutions/Henry\%20Nix/Henry\%20Nix\%20PRO C\%20BHA.htm.

https://yuokysurinda.wordpress.com/2018/02/24/beberapa-teori-hukum-tentang-tanggungjawab/

https://limbahbs.wordpress.com/2015/02/01/pengolahan-limbah/

https://idtesis.com/teori-lengkap-tentang-evaluasi-pengelolaan-limbah-menurut-para-ahli-dan-contoh-tesisevaluasi-pengelolaan-limbah/ diakses pada tanggal 8 Juli 2021.

Alexandre Kiss dan Dinah Shelton, 2007, Guide to International Environmental Law, Martinus Nijhoff Publishers, Leiden, hlm.16

https://hukumlingkunganinternasional.blogspot.com/2014/05/prinsip-prinsip-hukum-lingkungan.html.

ICJ Report 78 Slovakia V Hongaria (1997), Para 140

https://www.academia.edu/6719575/Prinsip_Prinsip_Pembangunan_Berkelanjutan_atau_Principle_of_Sustainab ility_Development. 